$11-2015$

\title{
Social Control of Reproduction and Breeding Monopolization in the Eusocial Snapping Shrimp Synalpheus elizabethae
}

STC Chak

Virginia Institute of Marine Science

DR Rubenstein

JE Duffy

Virginia Institute of Marine Science

Follow this and additional works at: https://scholarworks.wm.edu/vimsarticles

Part of the Ecology and Evolutionary Biology Commons, and the Marine Biology Commons

\section{Recommended Citation}

Chak, STC; Rubenstein, DR; and Duffy, JE, Social Control of Reproduction and Breeding Monopolization in the Eusocial Snapping Shrimp Synalpheus elizabethae (2015). American Naturalist, 186(5), 660-668. $10.1086 / 683132$

This Article is brought to you for free and open access by the Virginia Institute of Marine Science at W\&M ScholarWorks. It has been accepted for inclusion in VIMS Articles by an authorized administrator of W\&M ScholarWorks. For more information, please contact scholarworks@wm.edu. 


\title{
Social Control of Reproduction and Breeding Monopolization in the Eusocial Snapping Shrimp Synalpheus elizabethae
}

\author{
Solomon T. C. Chak, ${ }^{1, \star}$ Dustin R. Rubenstein, ${ }^{2}$ and J. Emmett Duffy ${ }^{1, \dagger}$ \\ 1. Virginia Institute of Marine Science, College of William and Mary, Gloucester Point, Virginia 23062; 2. Department of Ecology, Evolution, \\ and Environmental Biology, Columbia University, New York, New York 10027
}

Submitted February 17, 2015; Accepted June 4, 2015; Electronically published September 15, 2015

Online enhancements: appendixes. Dryad data: http://dx.doi.org/10.5061/dryad.6vb73.

\begin{abstract}
AвSTRACT: Understanding why individuals within altruistic societies forgo reproduction to raise others' offspring has fascinated scientists since Darwin. Although worker polymorphism is thought to have evolved only in sterile workers, worker subcastes appear to be common among social invertebrates and vertebrates. We asked whether sterility accompanies eusociality and morphological differentiation in snapping shrimps (Synalpheus) - the only known marine eusocial group. We show that workers in Synalpheus elizabethae are reproductively totipotent and that female - but not male - gonadal development and mating are mediated by the presence of a queen, apparently without physical aggression. In queenless experimental colonies, a single immature female worker typically became ovigerous, and no female workers matured in colonies with a resident queen. Thus, eusocial shrimp workers retain reproductive totipotency despite signs of morphological specialization. The failure of most female workers to mature is instead facultative and mediated by the presence of the queen, ensuring her reproductive monopoly.
\end{abstract}

Keywords: eusociality, reproductive skew, reproductive conflict, reproductive suppression, sterility, totipotency.

\section{Introduction}

Societies characterized by cooperation and reproductive altruism occur across the animal tree of life in a range of vertebrate and invertebrate taxonomic groups (Wilson 1971; Buskirk 1981; Brown 1987; Duffy 1996; Solomon and French 1997; Strassmann et al. 2000). Eusocial societies characterized by cooperative offspring care, overlapping generations, and reproductive division of labor (castes; Michener 1969; Wilson 1971) represent the pinnacle of social evolution but share many characteristics with other forms of altruistic groups. Although social animals have been suggested to form

\footnotetext{
* Corresponding author; e-mail: solomonchak@gmail.com.

${ }^{\dagger}$ Present address: Tennenbaum Marine Observatories Network, Smithsonian Institution, P.O. Box 37012, NHB MRC 106, Washington, DC 20013.

Am. Nat. 2015. Vol. 186, pp. 660-668. (C) 2015 by The University of Chicago. 0003-0147/2015/18605-56065\$15.00. All rights reserved. DOI: $10.1086 / 683132$
}

a continuum based on reproductive skew (Keller and Reeve 1994; Keller and Perrin 1995; Sherman et al. 1995), the monopolization of breeding positions appears to be maintained differently in different taxa (Crespi and Yanega 1995). Worker sterility - a defining characteristic of caste differentiation in eusocial species (Crespi and Yanega 1995; Boomsma 2007, 2009) — occurs in a variety of obligatorily eusocial insects (e.g., several ant genera, corbiculate bees, vespine wasps, and higher termites; Wilson 1971; Fletcher and Ross 1985; Thorne et al. 2003; Ratnieks et al. 2006), where workers are irreversibly committed to their nonreproductive roles (Boomsma 2013). In contrast, helpers in all cooperatively breeding vertebrates (birds and mammals), as well as workers in most facultatively eusocial insects (e.g., halictid bees, gall-forming thrips, and lower termites; Faulkes 1990; Chapman et al. 2002; Hart and Ratnieks 2005; Hartke and Baer 2011), are totipotent and retain the ability to reproduce.

Most facultatively eusocial species outside of the Hymenoptera are fortress defenders (Queller and Strassmann 1998) that nest within rich, concentrated food sources (e.g., clonal gall-forming aphids, ambrosia beetles, wood-dwelling termites, thrips, and two species of mole rats). However, very few - if any - of these fortress defenders, other than the higher termites, have evolved obligatory eusociality with an irreversible worker caste (Abe 1987; Noirot and Pasteels 1987). Why obligatory eusociality has evolved in higher termites but not in other fortress defenders remains unclear but may be related to food resources. Unlike most other fortress defenders, termites are central place foragers that obtain food from outside of the nest (Higashi et al. 1991; Heinze and Korb 2008; Boomsma 2013). Additionally, longlived host fortresses have been hypothesized to play a key role in the evolution of obligate eusociality (e.g., the ambrosia beetle Austroplatypus incompertus; Kent and Simpson 1992; Boomsma 2013), though this idea has not been tested.

The evolution of an irreversible worker caste is thought to be an important precursor to the evolution of morphological polymorphism of workers in eusocial species (i.e., 
the presence of specialized worker subcastes), because it allows colony-level selection to enhance worker efficiency and reproductive fitness of the colony (Oster and Wilson 1979). In support of this hypothesis, sterile workers in ants and higher termites show the most extreme forms of worker morphological and ecological polymorphism (Wilson 1971). Yet some fortress defenders express morphological differentiation among nonreproductives that are reproductively totipotent, including soldier neotenics in lower termites (Thorne et al. 2003) and the dispersive morph in naked mole rats (O'Riain et al. 1996). Therefore, it has been hypothesized that the presence of polymorphic reproductive soldiers may represent a natural transition toward obligate eusociality (Thorne et al. 2003; Boomsma 2013). However, it is not yet clear whether worker sterility is a necessary condition for the evolution of irreversible worker castes (i.e., obligatory eusociality), especially when observations have been limited to only a few lineages of insects and a single vertebrate group.

Exploring the generality of the relationship between worker sterility and worker polymorphism requires studying a range of animal lineages with a diversity of social systems. An ideal study species would be a noninsect, eusocial fortress defender such as the snapping shrimp Synalpheus elizabethae. Synalpheus shrimps live obligatorily within canals of live marine demosponges, which are stable, predatorfree, and typically long-lived fortresses (McMurray et al. 2008). Like most other fortress defenders, Synalpheus shrimps do not forage outside of the host sponge. Instead, they feed on host sponge tissues (Duriš et al. 2011) that may contain a significant amount of sponge-associated bacteria (Hentschel et al. 2006; Webster and Taylor 2012). Within the Caribbean gambarelloides clade of sponge-dwelling Synalpheus, eusociality appears to have evolved independently at least four times (Duffy et al. 2000; Morrison et al. 2004; Duffy and Macdonald 2010). Eusocial Synalpheus species live in groups that can contain up to several hundred individuals and one or a few breeding queens (Duffy 2007). In Synalpheus regalis, workers are related on average by 0.5 and are likely to be the offspring of a single queen (Duffy 1996). However, whether these eusocial Synalpheus have sterile workers and are obligatorily eusocial has not been tested.

Some eusocial Synalpheus species exhibit morphological differentiation between queens and workers (Duffy and Macdonald 1999) as well as among workers (as subcastes; Duffy 1998; Duffy et al. 2002; Tóth and Duffy 2008), suggesting that this group may be very similar to other obligatory eusocial species. For example, in Synalpheus filidigitus, the queen's major chela (snapping claw) is replaced with a smaller minor chela (Duffy and Macdonald 1999). Moreover, queens in most species have a brood pouch (i.e., extended pleura on the abdomen) that is not observed in female workers (Chak et al. 2015a). This degree of morpho- logical differentiation between queens and workers is suggestive of a true worker caste, similar to that observed in the eusocial ambrosia beetle (Kent and Simpson 1992). Additionally, large colonies of eusocial Synalpheus in several species exhibit a morphologically specialized group of large individuals that possess a bigger weapon (fighting claw) than other workers and who are more active in colony defense but show no external signs of reproductive maturity (Duffy 1998; Duffy et al. 2002; Tóth and Duffy 2008). These shrimp workers resemble the morphologically specialized caste in many obligatory eusocial insects, such as ants and higher termites, or facultatively eusocial species, such as lower termites and naked mole rats, that have reproductively totipotent workers.

Here we explore whether the fortress defender S. elizabethae shows parallels with other social insects and vertebrates in how eusociality, worker sterility, and morphological differentiation have coevolved. Our primary goal is to determine whether a eusocial species of Synalpheus has either reproductively totipotent workers that might represent an early stage of social evolution or sterile workers that might facilitate evolution of worker polymorphism, as in the Hymenoptera (Crespi and Yanega 1995; Boomsma 2013). We first test whether workers in S. elizabethae have lost or maintained the ability to reproduce by examining gonadal development. We then report on experiments designed to determine whether workers are capable of mating in the absence of the queen and whether mediation of worker development involves aggression on the part of queens or workers. Ultimately, our results will be important for understanding the nature of reproductive altruism and conflict in a taxonomic group that is similar to but distinct from other eusocial fortress defenders.

\section{Material and Methods}

\section{Gonadal Development of Workers in Wild Colonies}

To assess whether workers are sterile or totipotent, we obtained samples of the eusocial species Synalpheus elizabethae (Ríos and Duffy 2007) from five colonies in the Bocas del Toro region of Panama. Synalpheus elizabethae are most abundant in the demosponge Lissodendoryx colombiensis (Zea and Van Soest 1986) in this region of the Caribbean (McGrew and Hultgren 2011). We collected whole sponges with scuba from depths of 2-8 $\mathrm{m}$ from subtidal sandy patches near the west coast of Isla Colon, Bocas del Toro $\left(9.39712^{\circ} \mathrm{N}, 82.31760^{\circ} \mathrm{W}\right)$, between August and October 2011. Sponges were transported while submerged in seawater to the Smithsonian Tropical Research Institute's Bocas del Toro Research Station, where all shrimps inhabiting the sponges were removed and identified under light microscopy. Ovigerous individuals (hereafter, queens) 
possessed visible embryos under the abdomen. Non-ovigerous individuals (hereafter, workers) lacked visible embryos and were preserved in Davidson's fixative (3:3:2:1 of distilled water, $95 \%$ ethanol, $37 \%$ formaldehyde, and glacial acetic acid) for subsequent histological analysis to assess gonadal development. From the three largest colonies, we confirmed that S. elizabethae has a morphologically specialized group of large workers that possesses stronger weapons like its close relatives (Tóth and Duffy 2008; app. B; apps. A and B available online).

We chose 20 workers from each colony for histological examination. All workers were above the maturation sizethe size of the smallest individual in the population that had mature gonads (app. B). Carapace length (CL) and major chela length were measured from photographs as described by Tóth and Duffy (2008) using ImageJ, version 1.48 (Schneider et al. 2012). Specimens were decalcified overnight (in $0.1 \mathrm{~g} / \mathrm{mL}$ sodium citrate in $22.5 \%$ formic acid), dehydrated, and then infiltrated and embedded in paraffin using standard protocols (Humason 1979). Sagittal sections $(3-5 \mu \mathrm{m})$ were cut with a rotary microtome and mounted onto glass slides before staining with hematoxylin and eosin. Depending on an individual's CL, we examined six to 12 sets of three to five continuous sections, each separated by $20-30 \mu \mathrm{m}$, until at least half of the specimen was sectioned.

We scored each specimen for the presence of sperm, testes, developing oocytes, young ova, or mature ova (Bell and Lightner 1988). Mature ova had lipid-filled cytoplasms and were distinctively larger cells than young ova. Sperm were highly basophilic, with the distinct umbrella shape characteristic of decapod crustaceans, and were located in the testis, vas deferens, or an enlarged sac near the gonad opening (gonopore) at the base of the fifth walking leg. Individuals were ultimately categorized as (i) mature males with sperm and testis, (ii) immature males with testis lacking sperm, (iii) mature females with mature ova, or (iv) immature females with developing oocytes or young ova. We quantified the amount of sperm in mature males as the proportional area occupied by sperm cells in the enlarged sac located in the section that had the highest number of sperm for each specimen.

\section{Experimental Analysis of Worker Reproductive Capacity and Physical Aggression}

To determine the reproductive capacity of workers and whether breeding monopolization involves aggression on the part of queens or workers in S. elizabethae, we examined experimentally how the presence of the queen and the number of workers in the colony influenced worker gonadal development. We created vacant sponges as seminatural habitats for the shrimps (app. B) in the lab at the Smithsonian Tropical Research Institute's Bocas del Toro
Research Station between June and August 2013. A pilot experiment showed that 22 days was the optimal experimental duration to observe worker development and reproduction (app. B). We report combined data from the pilot and main experiments, since results did not differ between the two.

We initiated the experiment by collecting $S$. elizabethae from 16 sponges and dividing the shrimp from each sponge into three groups: (i) one queen and six workers (1Q/6W), (ii) queenless with six workers $(0 \mathrm{Q} / 6 \mathrm{~W})$, and (ii) one worker only $(0 \mathrm{Q} / 1 \mathrm{~W})$. Each of these shrimp composition treatments had 16 replicates. After 22 days, we preserved all shrimps in Davidson's fixative for histological examination of gonadal development. To determine whether the workers that became ovigerous had fertilized eggs, we compared the histology of eggs from ovigerous workers and from queens that remained ovigerous after the experiment. Finally, we recorded whether workers had lost their major chela as a measure of within-colony aggression.

\section{Statistical Analysis}

For the examination of gonadal development in workers from wild colonies, we determined whether mature and immature females differed in CL using a generalized linear mixed model, with maturity as a fixed factor and colony as a random block (slopes and intercepts were allowed to vary among colonies). The $P$ values were obtained from likelihood ratio tests. We also examined the relationship between CL and sperm amount, with colony as a random block. We then determined whether the percentage of mature workers in each colony differed between males and females using a Student's $t$-test. All analyses were performed with R, version 3.0.1 (R Development Core Team 2014).

Our analyses of the experimental manipulation were based on 24 replicate groups (i.e., groups of different shrimp composition treatment, each in a cup of vacant sponge), with an experimental duration of 22 days from both the pilot and the main experiments. Although we initially had 48 groups (16 replicates each for three treatments), we excluded 24 groups that either had vitellogenic workers at the beginning of the experiment, contained a queen that died during the experiment, or contained workers that were determined to have been all males or all females based on subsequent histological analyses (table A2; tables A1-A3, B1 available online). Vitellogenic workers had a visible mass of small developing ova internally within the cephalothorax between the stomach and the heart-we removed these replicates so that all workers at the beginning of the experiment had only immature gonads; thus, no worker had any head start in development. To analyze the results of the experiment, we first determined how many females in each group became reproductively mature (i.e., mature gonads as shown 
by histology). At the end of the experiment, most groups had only a single mature or ovigerous female worker (typically either ovigerous or with mature gonads; fig. A1; figs. A1A4, B1-B4 available online); hence, we categorized each group by the most developed female into ovigerous, mature, or immature. We then used two-tailed Fisher's exact tests to test whether worker development (of the most developed female in each sample) was affected by the absence of a queen $(0 \mathrm{Q} / 6 \mathrm{~W}$ vs. $1 \mathrm{Q} / 6 \mathrm{~W})$ or by social interactions (i.e., presence or absence of potential mate or potential competition with other same-sex individuals; 0Q/6W vs. 0Q/1W). Specifically, we tested whether the observed proportions of the three nominal groups (ovigerous, mature, and immature, focusing on the most developed female in each sample; fig. $1 B$; table A1) were independent between treatments, using groups (as opposed to individual shrimps) as replicates. The $P$ values were adjusted according to the HolmBonferroni method for multiple comparisons (Holm 1979). In the $0 \mathrm{Q} / 6 \mathrm{~W}$ treatment, we tested for a difference in $\mathrm{CL}$ between immature, mature, and ovigerous female workers using a one-way analysis of variance (ANOVA).

To investigate the effect of treatment on levels of social conflict among workers, we used data for experimental durations of 7, 11, and 22 days from the pilot and main experiments. We tested whether worker mortality (i.e., the pro- portion of dead workers) differed between the $1 \mathrm{Q} / 6 \mathrm{~W}$ and 0Q/6W treatments using Poisson regression. We then tested whether worker injury (i.e., the proportion of workers that had lost a major chela) differed between treatments using a generalized linear mixed model with binomial response.

\section{Results}

\section{Gonadal Development of Workers in Wild Colonies}

The five field-collected Synalpheus elizabethae colonies ranged in size from 84 to 344 individuals, containing one to seven queens each (table A1). Based on histology, none of the 112 adult workers we examined was sterile. Instead, all female $(n=52)$ and male $(n=60)$ workers examined histologically showed signs of gonadal development in which sperm, testis, or various stages of ova were present. However, the level of gonadal maturity differed by sex; only 17 of 52 female workers were mature (mean $\pm \mathrm{SD}=38.4 \pm$ $20.9 \%$ ), whereas 58 of 60 male workers were mature $($ mean $\pm \mathrm{SD}=97.5 \pm 5.6 \%$ ). Thus, significantly fewer female workers than male workers had mature gonads $\left(t_{5}=\right.$ 6.06, $P=.0023$; table A1; fig. $1 A$ ). Gonadal maturity was not related to size in either sex; immature and mature females were similar in CL $\left(\chi_{1}^{2}=0.13, P=.72\right.$; fig. A2), and
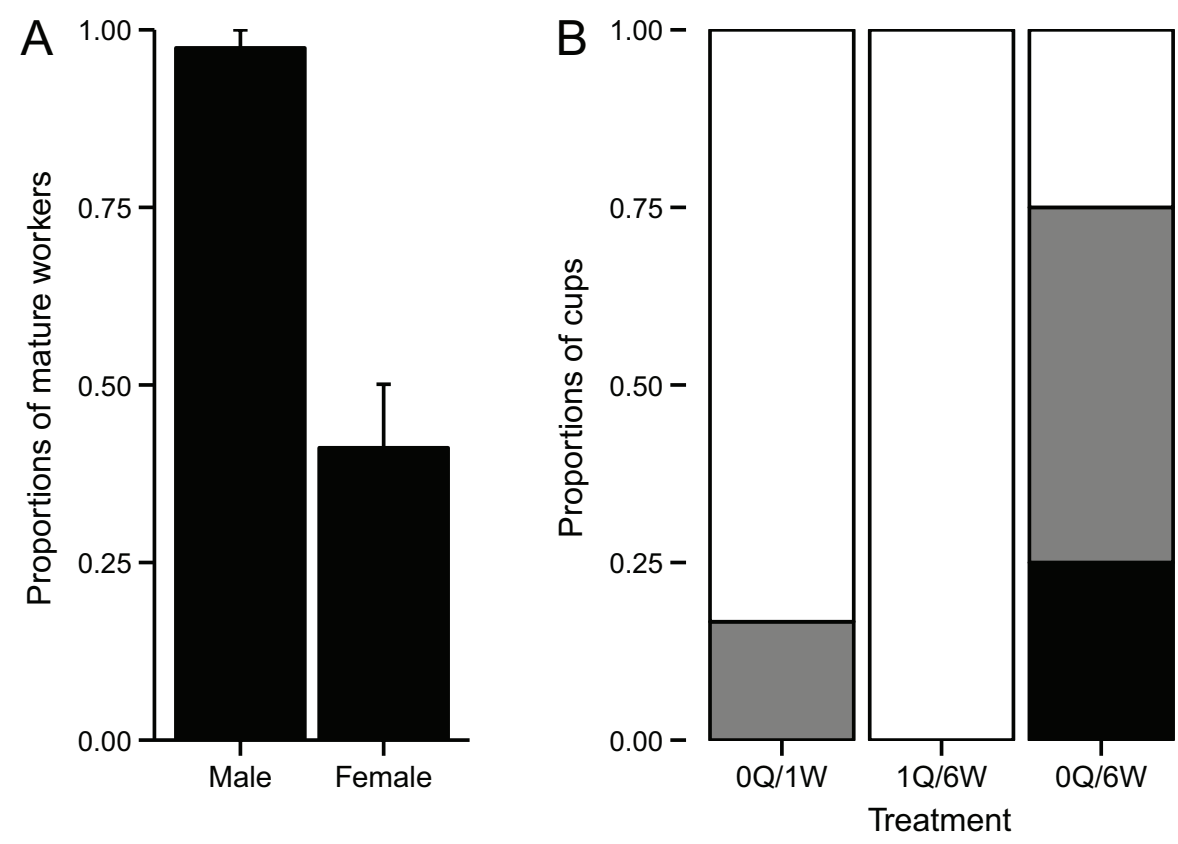

Gonadal dev.

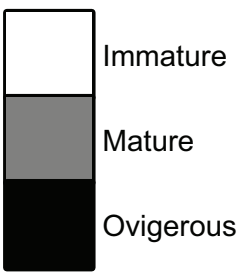

Figure 1: Gonadal development of workers in wild colonies $(A)$ and in experimental colonies $(B)$ of Synalpheus elizabethae. A, Mean ( \pm SE proportion) of mature workers (mature + ovigerous) per colony was significantly higher for males than for females in wild colonies $\left(t_{5}=6.06\right.$, $P=.0023) . B$, Degree of gonadal development of the most developed female worker in experimental groups after 22 days. Presence of a queen significantly suppressed worker gonadal development $(1 \mathrm{Q} / 6 \mathrm{~W}$ vs. $0 \mathrm{Q} / 6 \mathrm{~W}: P=.029)$, and female workers usually failed to mature when held alone $(0 \mathrm{Q} / 6 \mathrm{~W}$ vs. $0 \mathrm{Q} / 1 \mathrm{~W}: P=.17)$. Workers became ovigerous only in the absence of a resident queen and a potential mate (0Q/6W). Data are available in the Dryad Digital Repository: http://dx.doi.org/10.5061/dryad.6vb73 (Chak et al. 2015b). 
the amount of sperm did not correlate with CL in males $\left(\chi_{1}^{2}=1.48, P=.22\right)$.

\section{Experimental Analysis of Worker Reproductive Capacity}

We analyzed each experimental group according to the degree of gonadal development of the single most developed female worker in the group. Of the 12 queenless groups of workers $(0 \mathrm{Q} / 6 \mathrm{~W})$ included in the final analysis, three groups developed a single mature ovigerous worker (fig. $2 \mathrm{~A}$, $2 B$ ), and six developed a mature but nonovigerous worker (figs. $1 B, 2 C, 2 D$; table A2). In contrast, in the six groups with multiple workers and a single queen $(1 \mathrm{Q} / 6 \mathrm{~W})$, no workers reached maturity. Thus, the presence of a queen significantly affected worker gonadal development, and when queens were removed, workers started transitioning into new queens in significantly more groups than in those where queens were left intact $(1 \mathrm{Q} / 6 \mathrm{~W}$ vs. $0 \mathrm{Q} / 6 \mathrm{~W}: P=$ .029 ; fig. $1 B$ ). Finally, female workers usually failed to mature when held alone $(0 \mathrm{Q} / 6 \mathrm{~W}$ vs. $0 \mathrm{Q} / 1 \mathrm{~W}: P=.17$; fig. $1 B)$; only one of six cups in this treatment developed a mature worker. This pattern was consistent even in the few cases in which workers had initial gonadal development (i.e., with visible gonads at the start of the experiment), as ovigerous workers were still found only in queenless groups $(0 \mathrm{Q} / 6 \mathrm{~W}$ : 1 of 4; table A3). Carapace length (CL, an index of body size) did not differ among mature, immature, and ovigerous female workers in the treatment where they co-occurred (0Q/6W: one-way ANOVA, $F_{2,26}=0.41, P=.67$ ).

Histological examination showed that workers that became ovigerous had fertilized eggs. Eggs from queens and

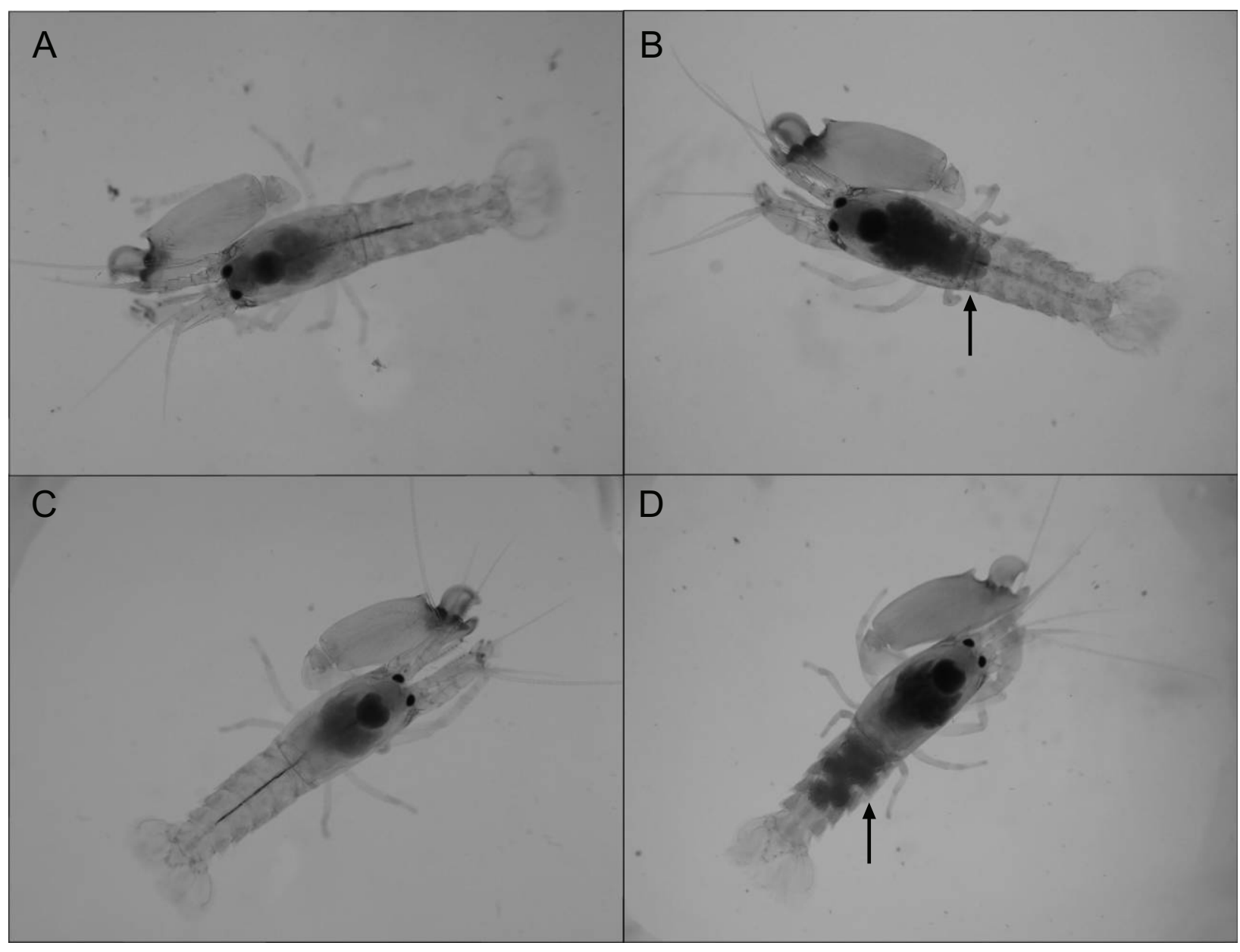

Figure 2: Reproductive development of two Synalpheus elizabethae workers from immature $(A)$ into mature $(B)$ and from immature $(C)$ into ovigerous $(D)$ in queenless experimental colonies. Arrows indicate developing gonad in $B$ and eggs in $D$. In our experiment, the reproductive developments of all workers were further examined histologically. 
from ovigerous workers showed no structural difference: all eggs had differentiated cells characteristic of fertilized eggs (fig. A3). Although females in some species of alpheid shrimp can ovulate without mating, unfertilized eggs are much smaller than fertilized eggs and have a chalky appearance, making unfertilized eggs easily recognizable (Knowlton 1973; Felder 1982). In our study, all ovigerous female workers examined had large, nonchalky eggs, similar in appearance to eggs of other queens in captivity and the wild, suggesting that they were fertilized.

\section{Experimental Analysis of Physical Aggression}

Across experimental durations from 7 to 22 days, worker injuries (i.e., the loss of the major chela) were more frequent in queenless groups $(0 \mathrm{Q} / 6 \mathrm{~W})$ than in groups containing a queen $\left(1 \mathrm{Q} / 6 \mathrm{~W}: \chi_{1}^{2}=9.87, P=.0017\right)$. However, worker mortality did not differ among treatments $\left(\chi_{1}^{2}=1.44, P=\right.$ .23; fig. 3).

\section{Discussion}

The combination of our field studies and lab experiments demonstrates that (i) workers in the eusocial snapping shrimp Synalpheus elizabethae are not sterile, with individuals of both sexes showing signs of gonadal development, and (ii) immature workers can mature and reproduce when the queen is absent. Our experimental results support observations of gonadal development in workers of four other eusocial species of Synalpheus (Chak et al. 2015a). Therefore, worker sterility does not appear to have evolved in eusocial snapping shrimps, which is consistent with what has been found in other facultatively eusocial fortress defenders that show some degree of morphological specialization despite having reproductively totipotent workers (e.g., gall-forming thrips, lower termites, and naked mole rats; O'Riain et al. 1996; Chapman et al. 2002; Thorne et al. 2003; Boomsma 2013). Thus, the similarity among Synalpheus and these quite distinct lineages of facultatively eusocial animals supports the generality of a model for evolution of social organization that bears strong similarities among disparate animal taxa. Moreover, the recent evolution of eusociality in Synalpheus (Morrison et al. 2004) suggests that worker polymorphism may indeed evolve before workers achieve permanent sterility.

Although most male workers in S. elizabethae were reproductively mature $(98 \%)$, most female workers were reproductively immature $(>60 \%)$. These reproductively immature females were similar in size to the mature females and were not sterile, since our experimental manipulation revealed that they could develop into mature ovigerous individuals with fertilized eggs in as little as 3 weeks after queen removal. These sex-specific patterns of gonadal development in S. elizabethae suggest that female-but not male-workers show reduced gonadal development. Our experimental manipulations further demonstrated that this reduced reproductive development is mediated by the presence of the queen. That is, in the presence of a mature queen, all female workers remained immature, but when the queen was experimentally removed, a single female worker in most colonies became ovigerous or at least developed mature gonads. Moreover, in nearly all cases, only one of the six workers became mature after queen removal, indi-
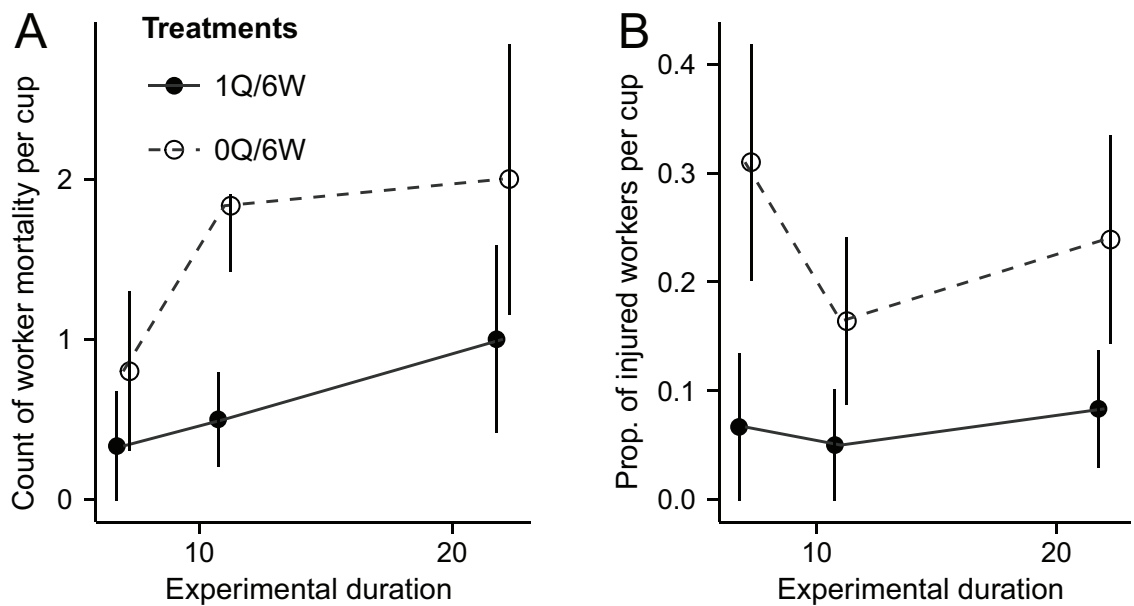

Figure 3: Mortality $(A)$ and injuries (i.e., loss of major chela; $B$ ) among workers in treatments of different experimental duration with and without a queen (mean \pm SE). Presence of queens did not significantly influence worker mortality, but worker injury was more frequent in the absence of a queen. 
cating that once a worker becomes a replacement queen, she can affect others' reproductive development.

Our results also suggest that workers are able and willing to mate with their nestmates in an artificial setting, highlighting potential hidden reproductive conflict in eusocial colonies of S. elizabethae. Despite the presence of reproductively immature female workers, we found that many female workers in this species had mature gonads in wild colonies (38.4\%). However, none of the female workers in these wild colonies had breeding dress, a typical morphological modification in breeding female caridean shrimps in which a brood pouch forms to hold spawned eggs under their abdomens (Bauer 2004). Therefore, despite being reproductively mature, all female workers remained unmated; only queens produced fertilized eggs in the wild. Therefore, eusocial Synalpheus are similar to many facultative eusocial species in which workers are hopeful reproductives that only reproduce when the opportunity arises (Thorne et al. 2002).

Interestingly, although half of the natural colonies of $S$. elizabethae at our site in Panama had a single queen, some had as many as 20 (mean $\pm \mathrm{SD}=3.58 \pm 4.09 \%$ ). In fact, there was a strong positive correlation between colony size and the number of queens among 72 colonies of S. elizabethae collected from Bocas del Toro from 2007 to 2013 (fig. A4). This may suggest that the degree to which queens can mediate worker development and monopolize breeding varies among colonies (Hultgren et al. 2016) and is probably limited by the number of individuals that the queen can influence (Michener 1990; Keller and Nonacs 1993; Strohm and Bordon-Hauser 2003), whether via behavior or chemical signals. In other words, as colony size increases, breeding monopolization becomes more difficult, and other females are able to reproduce, as has been hypothesized previously (Rubenstein and Shen 2009). On the other hand, theory also predicts that reproductive sharing (i.e., having multiple queens per sponge) may help to reduce reproductive conflict, either between queens and workers or among workers, when larger colonies provide greater reproductive benefits (Rubenstein and Shen 2009; Rubenstein 2012). However, ecological constraints on queen mortality, queen longevity, dispersal, and independent colony founding may also explain the presence of multiqueen colonies (Bourke and Heinze 1994; Keller 1995).

Finally, our observation that worker injuries were lower when the queen was present than when the queen was removed indicates that the mechanism of worker breeding monopolization by queens in S. elizabethae and probably other eusocial Synalpheus species is not mediated by the queen's physical aggression toward workers, as is also true of various social invertebrates and vertebrates (Clarke and Faulkes 2001; Liebig et al. 2005; Cronin and Field 2007; Young and Bennett 2013; Bell et al. 2014; Cant et al. 2014). Chemical mechanisms such as pheromones (Keller and
Nonacs 1993; Le Conte and Hefetz 2008; Holman et al. 2010; Matsuura et al. 2010) from the queen seem likely to be responsible for suppressing female worker maturation given their widespread presence in crustaceans (Breithaupt and Thiel 2010) and arthropods in general (Blomquist and Bagnères 2010). Indeed, direct queen aggression and policing (Ratnieks et al. 2006; Hoffmann and Korb 2011) are unlikely in Synalpheus because queens in eusocial species tend to have smaller major chelae than workers (Tóth and Duffy 2008) and because colonies of most eusocial shrimps are likely too large for a queen to behaviorally prevent other pairs from mating. Additionally, the observation that worker injuries (but not mortality) increased in queenless groups of workers where a single worker eventually became ovigerous or mature suggests that there is indeed overt aggression when a queen dies and an opportunity arises for others to breed. In other words, workers appear to fight for succession to become the dominant breeder when a queen dies; this is similar to naked mole rats (Clarke and Faulkes 1997) but not lower termites (Hoffmann and Korb 2011).

In summary, we have shown that workers of both sexes in the eusocial snapping shrimp S. elizabethae have retained reproductive capacity, as is true in many fortress defender eusocial species that exhibit food-shelter coincidence (Crespi 1994), but also that the presence of a healthy queen can mediate gonadal development only in females. Breeding monopolization by the queen evidently occurs without physical aggression, but in queenless experimental colonies, workers fought for vacated breeding positions, and ultimately only one filled the reproductive vacancy. Therefore, in facultatively eusocial shrimp, some degrees of ecological and morphological polymorphism can evolve in the absence of sterility (as is also true of nonsocial animals; West-Eberhard 2003). Moreover, the sex-specific pattern of reduced worker development in eusocial shrimps appears to be unique among invertebrates. With a better understanding of the mechanisms that govern reproductive skew and colony dynamics in eusocial shrimps, we are moving toward a more unified appreciation of animal sociality across diverse lineages - vertebrates and invertebrates - and ecosystems, from the terrestrial to the marine.

\section{Acknowledgments}

We are grateful to S. Bornbusch, J. Kealey, K. W. Leong, and staff from the Bocas del Toro Research Station for field assistance; J. D. Shields and S. E. Sullivan for assistance with the histology; and K. Hultgren for providing comments on previous versions of the article. S.T.C.C. was funded by the Smithsonian Tropical Research Institute Short-Term Fellowship Program. D.R.R. was supported by the US National Science Foundation (IOS-1121435 and 
IOS-1257530). J.E.D. was funded by the US National Science Foundation (IOS-1121716). This work also benefited from the Smithsonian Institution's Caribbean Coral Reef Ecosystem Program. This article is contribution 3469 of the Virginia Institute of Marine Science, College of William and Mary.

\section{Literature Cited}

Abe, T. 1987. Evolution of the life types in termites. Pages 125-148 in S. Kawano, J. H. Connel, and T. Hidaka, eds. Evolution, coadaptation, and biotic communities. University of Tokyo Press, Tokyo.

Bauer, R. T. 2004. Remarkable shrimps: adaptations and natural history of the carideans. University of Oklahoma Press, Norman.

Bell, M. B., M. A. Cant, C. Borgeaud, N. Thavarajah, J. Samson, and T. H. Clutton-Brock. 2014. Suppressing subordinate reproduction provides benefits to dominants in cooperative societies of meerkats. Nature Communications 5:4499.

Bell, T. A., and D. V. Lightner. 1988. A handbook of normal penaeid shrimp histology. World Aquaculture Society, Baton Rouge, LA.

Blomquist, G. J., and A.-G. Bagnères. 2010. Insect hydrocarbons: biology, biochemistry, and chemical ecology. Cambridge University Press, Cambridge.

Boomsma, J. J. 2007. Kin selection versus sexual selection: why the ends do not meet. Current Biology 17:R673-R683.

2009. Lifetime monogamy and the evolution of eusociality. Philosophical Transactions of the Roval Society B: Biological Sciences 364:3191-3207.

. 2013. Beyond promiscuity: mate-choice commitments in social breeding. Philosophical Transactions of the Roval Society B: Biological Sciences 368:20120050.

Bourke, A. F. G., and J. Heinze. 1994. The ecology of communal breeding: the case of multiple-queen leptothoracine ants. Philosophical Transactions of the Roval Society B: Biological Sciences 345:359-372

Breithaupt, T., and M. Thiel. 2010. Chemical communication in crustaceans. Springer, New York.

Brown, J. L. 1987. Helping and communal breeding in birds. Princeton University Press, Princeton, NJ.

Buskirk, R. 1981. Sociality in the Arachnida: social insects. Vol. 2. Academic Press, New York

Cant, M. A., H. J. Nichols, R. A. Johnstone, and S. J. Hodge. 2014 Policing of reproduction by hidden threats in a cooperative mammal. Proceedings of the National Academv of Sciences of the USA 111:326-330

Chak, S. T. C., J. E. Duffy, and D. R. Rubenstein. 2015a. Reproductive skew drives patterns of sexual dimorphism in sponge-dwelling snapping shrimps. Proceedings of the Roval Society B: Biological Sciences 282:20150342.

Chak, S. T. C., D. R. Rubenstein, and J. E. Duffy. 2015b. Data from Social control of reproduction and breeding monopolization in the eusocial snapping shrimp Synalpheus elizabethae. American Naturalist, Dryad Digital Repository, http://dx.doi.org/10.5061/dryad.6vb73.

Chapman, T. W., B. D. Kranz, K.-L. Bejah, D. C. Morris, M. P. Schwarz, and B. J. Crespi. 2002. The evolution of soldier reproduction in social thrips. Behavioral Ecology 13:519-525.

Clarke, F. M., and C. C. Faulkes. 1997. Dominance and queen succession in captive colonies of the eusocial naked mole-rat, Heteroce- phalus glaber. Proceedings of the Roval Societv B: Biological Sciences 264:993-1000.

2001. Intracolony aggression in the eusocial naked mole-rat, Heterocephalus glaber. Animal Behaviour 61:311-324.

Crespi, B. 1994. Three conditions for the evolution of eusociality: are they sufficient? Insectes Sociaux 41:395-400.

Crespi, B. J., and D. Yanega. 1995. The definition of eusociality. Behavioral Ecology 6:109-115.

Cronin, A. L., and J. Field. 2007. Social aggression in an age-dependent dominance hierarchy. Behaviour 144:753-765.

Duffy, J. E. 1996. Eusociality in a coral-reef shrimp. Nature 381:512514.

. 1998. On the frequency of eusociality in snapping shrimps (Decapoda: Alpheidae), with description of a second eusocial species. Bulletin of Marine Science 63:387-400.

2007. Ecology and evolution of eusociality in sponge-dwelling shrimp. Pages 387-409 in J. E. Duffy and M. Thiel, eds. Evolutionary ecology of social and sexual systems: crustaceans as model organisms. Oxford University Press, New York.

Duffy, J. E., and K. S. Macdonald. 1999. Colony structure of the social snapping shrimp Synalpheus filidigitus in Belize. Journal of Crustacean Biology 19:283-292.

- 2010. Kin structure, ecology and the evolution of social organization in shrimp: a comparative analysis. Proceedings of the Roval Society B: Biological Sciences 277:575-584

Duffy, J. E., C. L. Morrison, and K. S. Macdonald. 2002. Colony defense and behavioral differentiation in the eusocial shrimp Synalpheus regalis. Behavioral Ecology and Sociobiology 51:488-495.

Duffy, J. E., C. L. Morrison, and R. Ríos. 2000. Multiple origins of eusociality among sponge-dwelling shrimps (Synalpheus). Evolution 54:503-516.

Ďuriš, Z., I. Horká, P. J. Juračka, A. Petrusek, and F. Sandford. 2011. These squatters are not innocent: the evidence of parasitism in sponge-inhabiting shrimps. PLoS ONE 6:e21987.

Faulkes, C. 1990. Social suppression of reproduction in the naked mole-rat, Heterocephalus glaber. $\mathrm{PhD}$ thesis, University of London.

Felder, D. L. 1982. Reproduction of the snapping shrimps Synalpheus fritzmuelleri and S. apioceros (Crustacea: Decapoda: Alpheidae) on a sublittoral reef off Texas. Journal of Crustacean Biology 2:535-543.

Fletcher, D. J. C., and K. G. Ross. 1985. Regulation of reproduction in eusocial Hymenoptera. Annual Review of Entomology 30:319-343.

Hart, A. G., and F. L. Ratnieks. 2005. Crossing the taxonomic divide: conflict and its resolution in societies of reproductively totipotent individuals. Journal of Evolutionary Biology 18:383-395.

Hartke, T. R., and B. Baer. 2011. The mating biology of termites: a comparative review. Animal Behaviour 82:927-936.

Heinze, J., and J. Korb. 2008. The ecology of social life: a synthesis. Pages 245-259 in J. Korb, and J. Heinze, eds. Ecology of social evolution. Springer, Berlin.

Hentschel, U., K. M. Usher, and M. W. Taylor. 2006. Marine sponges as microbial fermenters. FEMS Microbiology Ecology 55:167-177.

Higashi, M., N. Yamamura, T. Abe, and T. Burns. 1991. Why don't all termite species have a sterile worker caste? Proceedings of the Roval Society B: Biological Sciences 246:25-29.

Hoffmann, K., and J. Korb. 2011. Is there conflict over direct reproduction in lower termite colonies? Animal Behaviour 81:265-274.

Holm, S. 1979. A simple sequentially rejective multiple test procedure. Scandinavian Journal of Statistics 6:65-70.

Holman, L., C. G. Jorgensen, J. Nielsen, and P. d'Ettorre. 2010. Identification of an ant queen pheromone regulating worker sterility. 
Proceedings of the Roval Society B: Biological Sciences 277:37933800.

Hultgren, K. M., J. E. Duffy, and D. R. Rubenstein. 2016. Sociality in shrimps. In D. R. Rubenstein and P. Abbot, eds. Comparative social evolution. Cambridge University Press, Cambridge (forthcoming).

Humason, G. L. 1979. Animal tissue techniques. W. H. Freeman, San Francisco.

Keller, L. 1995. Social life: the paradox of multiple-queen colonies. Trends in Ecology and Evolution 10:355-360.

Keller, L., and P. Nonacs. 1993. The role of queen pheromones in social insects-queen control or queen signal. Animal Behaviour 45:787-794.

Keller, L., and N. Perrin. 1995. Quantifying the level of eusociality. Proceedings of the Roval Society B: Biological Sciences 260:311-315.

Keller, L., and H. Reeve. 1994. Partitioning of reproduction in animal societies. Trends in Ecology and Evolution 9:98-102.

Kent, D., and J. Simpson. 1992. Eusociality in the beetle Austroplatypus incompertus (Coleoptera: Curculionidae). Naturwissenschaften 79: $86-87$.

Knowlton, R. E. 1973. Larval development of the snapping shrimp Alpheus heterochaelis Say, reared in the laboratory. Journal of Natural History 7:273-306.

Le Conte, Y., and A. Hefetz. 2008. Primer pheromones in social hymenoptera. Annual Review of Entomology 53:523-542.

Liebig, J., T. Monnin, and S. Turillazzi. 2005. Direct assessment of queen quality and lack of worker suppression in a paper wasp. Proceedings of the Roval Societv B: Biological Sciences 272:1339-1344.

Matsuura, K., C. Himuro, T. Yokoi, Y. Yamamoto, E. L. Vargo, and L. Keller. 2010. Identification of a pheromone regulating caste differentiation in termites. Proceedings of the National Academv of Sciences of the USA 107:12963-12968.

McGrew, M., and K. M. Hultgren. 2011. Bopyrid parasite infestation affects activity levels and morphology of the eusocial snapping shrimp Synalpheus elizabethae. Marine Ecology Progress Series 431:195-204.

McMurray, S. E., J. E. Blum, and J. R. Pawlik. 2008. Redwood of the reef: growth and age of the giant barrel sponge Xestospongia muta in the Florida Keys. Marine Biology 155:159-171.

Michener, C. 1990. Reproduction and castes in social halictine bees. Pages 77-121 in W. Engels, ed. Social insects. Springer, Berlin.

Michener, C. D. 1969. Comparative social behavior of bees. Annual Review of Entomology 14:299-342.

Morrison, C. L., R. Ríos, and J. E. Duffy. 2004. Phylogenetic evidence for an ancient rapid radiation of Caribbean sponge-dwelling snapping shrimps (Synalpheus). Molecular Phylogenetics and Evolution 30:563-581.

Noirot, C., and J. Pasteels. 1987. Ontogenetic development and evolution of the worker caste in termites. Cellular and Molecular Life Sciences 43:851-860.

O’Riain, M. J., J. U. M. Jarvis, and C. G. Faulkes. 1996. A dispersive morph in the naked mole-rat. Nature 380:619-621.

Oster, G. F., and E. O. Wilson. 1979. Caste and ecology in the social insects. Princeton University Press, Princeton, NJ.

Queller, D. C., and J. E. Strassmann. 1998. Kin selection and social insects. Bioscience 48:165-175.
R Development Core Team. 2014. R: a language and environmen for statistical computing. R Foundation for Statistical Computing, Vienna.

Ratnieks, F. L., K. R. Foster, and T. Wenseleers. 2006. Conflict resolution in insect societies. Annual Review of Entomology 51:581-608.

Ríos, R., and J. E. Duffy. 2007. A review of the sponge-dwelling snapping shrimp from Carrie Bow Cay, Belize, with description of Zuzalpheus, new genus, and six new species (Crustacea:Decapoda: Alpheidae). Zootaxa 1602:1-89.

Rubenstein, D. R. 2012. Family feuds: social competition and sexual conflict in complex societies. Philosophical Transactions of the Roval Society B: Biological Sciences 367:2304-2313.

Rubenstein, D. R., and S. F. Shen. 2009. Reproductive conflict and the costs of social status in cooperatively breeding vertebrates. American Naturalist 173:650-661.

Schneider, C. A., W. S. Rasband, and K. W. Eliceiri. 2012. NIH Image to ImageJ: 25 years of image analysis. Nature Methods 9:671-675.

Sherman, P. W., E. A. Lacey, H. K. Reeve, and L. Keller. 1995. The eusociality continuum. Behavioral Ecology 6:102-108.

Solomon, N. G., and J. A. French. 1997. Cooperative breeding in mammals. Cambridge University Press, New York.

Strassmann, J. E., Y. Zhu, and D. C. Queller. 2000. Altruism and social cheating in the social amoeba Dictyostelium discoideum. $\mathrm{Na}$ ture 408:965-967.

Strohm, E., and A. Bordon-Hauser. 2003. Advantages and disadvantages of large colony size in a halictid bee: the queen's perspective. Behavioral Ecology 14:546-553.

Thorne, B. L., N. L. Breisch, and M. I. Haverty. 2002. Longevity of kings and queens and first time of production of fertile progeny in dampwood termite (Isoptera; Termopsidae; Zootermopsis) colonies with different reproductive structures. ogy 71:1030-1041.

Thorne, B. L., N. L. Breisch, and M. L. Muscedere. 2003. Evolution of eusociality and the soldier caste in termites: influence of intraspecific competition and accelerated inheritance. Proceedings of the National Academy of Sciences of the USA 100:12808-12813.

Tóth, E., and J. E. Duffy. 2008. Influence of sociality on allometric growth and morphological differentiation in sponge-dwelling alpheid shrimp. Biological Journal of the Linnean Society 94:527-540.

Webster, N. S., and M. W. Taylor. 2012. Marine sponges and their microbial symbionts: love and other relationships. Environmental Microbiology 14:335-346.

West-Eberhard, M. J. 2003. Developmental plasticity and evolution. Oxford University Press, Oxford.

Wilson, E. O. 1971. The insect societies. Harvard University Press /Belknap, Cambridge, MA.

Young, A. J., and N. C. Bennett. 2013. Intra-sexual selection in cooperative mammals and birds: why are females not bigger and better armed? Philosophical Transactions of the Roval Societv B: Biological Sciences 368:20130075.

Zea, S., and R. Van Soest. 1986. Three new species of sponges from the Colombian Caribbean. Bulletin of Marine Science 38:355-365.

Natural History Editor: Mark A. McPeek 